Jurnal Ilmiah Farmasi 16(1) Januari-Juli 2020, 1-89

ISSN: $1693-8666$

available at http://journal.uii.ac.id/index.php/JIF

\title{
Acute toxicity study of Andrographis paniculata (Burm.f) Ness herbs and Gynura procumbens (Merr) leaves extracts combination
}

\section{Studi toksisitas akut kombinasi ekstrak daun Andrographis paniculata (Burm.f) dan Gynura procumbens (Merr)}

\author{
Kurnia Rahayu Purnomo Sari*, Nofran Putra Pratama, Nadia Husna \\ Prodi Farmasi (S-1) Fakultas Kesehatan, Universitas Jenderal Achmad Yani Yogyakarta \\ *Corresponding author: kurniarahayupurnamasari@gmail.com
}

\begin{abstract}
Background: Development of medical plants as an alternative treatment needs support in terms of scientific evidence to increase public confidence to ensure the safety of its use. Recent research on Andrographis paniculata (Burm. f) Ness and Gynura procumbens (Lour.) Merr showed that the combination of these extracts has a potential to be developed into antihyperglycemic agent and there's no any potential toxicity for each extract.

Objective: The aim of this study was to evaluate the acute toxicity level of these two extracts combination. From this research, it is expected that information can be obtained regarding the safety of extracts to support the further development of the extract combination.

Method: The method that used in this research is based on OECD 423. Observation was intensively done to animal behavior $4 \mathrm{~h}$ after acute exposure and continued up to 14 days after acute exposure to evaluate whether there were animal died. After the 15 days, all the animals were sacrificed and the vital organ was isolated for histological study.

Results: The results showed that the exposure of these combination didn't caused any to toxicity symptoms and there's no animals died. Histological study on hepar showed that there's no mayor damage in the hepar even after exposure of $2000 \mathrm{mg} / \mathrm{kgBW}$ dose.

Conclusion: The combination of ethanol extract of $A$. paniculata herbs and G. procumbens leaves was categorized as unclassified ( $>2000 \mathrm{mg} / \mathrm{kgBW}$ ) in term of toxicity levels based on Globally Harmonized Classification System.

Keywords: Andrographis paniculata (Burm.f) Ness, Gynura procumbens (Lour.) Merr, acute toxicity

\section{Intisari}

Latar belakang: Pengembangan tanaman obat sebagai alternatif pengobatan perlu dukungan dari segi scientific evidence untuk meningkatkan kepercayaan masyarakat dan menjamin keamanan penggunaannya. Penelitian terbaru tentang sambiloto dan sambung nyawa menunjukkan bahwa kombinasi ekstrak tersebut berpotensi untuk dikembangkan menjadi agen antihiperglikemia dan dibutuhkan pemastian keamanannya.

Tujuan: Penelitian bertujuan untuk mengevaluasi potensi ketoksikan secara akut kombinasi ekstrak larut etanol herba sambiloto dan daun sambung nyawa.

Metode: Metode yang digunakan pada penelitian ini mengacu pada panduan OECD 423. Pengamatan yang dilakukan termasuk pada tingkah laku hewan uji tikus betina galur Wistar berjumlah 15 ekor, secara intensif terhadap gejala toksisitas selama 4 jam awal setelah paparan sediaan uji kemudian dilanjutkan hingga 14 hari pasca paparan untuk melihat ada/tidaknya hewan uji yang mati. Pada hari ke-15, seluruh hewan uji dikorbankan dan dibedah untuk diisolasi, ditimbang organ vitalnya dan dilakukan pengamatan histologi.

Hasil: Hasil penelitian menunjukkan bahwa kombinasi ekstrak tersebut tidak menyebabkan gejala toksik terhadap hewan uji dan tidak ada satupun hewan uji yang mati. Hasil histopatologi organ
\end{abstract}


hepar menunjukkan bahwa kombinasi ekstrak ini tidak menunjukkan efek berbahaya pada organ hepar hewan uji yang telah diberi paparan akut dengan dosis $2000 \mathrm{mg} / \mathrm{kgBB}$.

Kesimpulan: Ketoksikan kombinasi ekstrak larut etanol herba sambiloto dan daun sambung nyawa masuk dalam kategori unclassified (>2000mg/kgBB) menurut Globally Harmonized Classification System.

Kata kunci : Andrographis paniculata (Burm.f) Ness, Gynura procumbens (Lour.) Merr, toksisitas akut

\section{Pendahuluan}

Indonesia memiliki keanekaragaman hayati yang sangat beragam. Banyak tanaman yang telah dimanfaatkan oleh masyarakat dalam berbagai hal termasuk untuk pengobatan sebagai obat tradisional. Saat ini, eksplorasi khasiat tanaman herbal telah banyak dilakukan. Banyak tanaman herbal yang diteliti khasiatnya dalam bentuk ekstrak tunggal. Di sisi lain, eksplorasi kombinasi tanaman obat dapat menjadi alternatif dalam pengembangan tanaman obat untuk mendapatkan hasil atau keuntungan yang lebih baik dalam terapi penyakit. Salah satunya adalah herba sambiloto (Andrographis paniculata (Burm.f) Ness) dan daun sambung nyawa (Gynura procumbens (Lour.) Merr) yang telah dikenal terkait efek hipoglikemiknya.

Berbagai penelitian yang menggunakan herba sambiloto dan sambung nyawa secara tunggal maupun dalam bentuk kombinasi dengan ekstrak lain telah banyak dilakukan. Salah satunya adalah terkait aktivitas ekstrak tunggal sambiloto dan ekstrak tunggal sambung nyawa sebagai agen hipoglikemia (Algariri, et al., 2014; Reyes et al., 2006; Zhang \& Tan, 2000a, 2000b). Ekstrak sambung nyawa juga diketahui memiliki kemampuan atau manfaat sebagai antioksidan (Puangpronpitag et al., 2010).

Pengembangan obat herbal harus terus dilakukan secara berkesinambungan dan jangan sampai terputus pada satu tahap hingga uji farmakologi untuk bisa dimanfaatkan secara luas. Penelitian terkait efek herba sambiloto dan daun sambung nyawa yang diberikan secara kombinasi sebagai agen hipoglikemia telah dilakukan sejak tahun 2015 untuk mendapatkan komposisi perbandingan ekstrak kombinasi yang optimal (Sari et al., 2015). Sehingga langkah selanjutnya adalah studi untuk mengetahui potensi toksisitas akut apabila kedua ekstrak tersebut diberikan secara kombinasi. Apabila kombinasi kedua ekstrak tidak menyebabkan toksisitas akut pada hewan uji, maka pengembangan selanjutnya adalah untuk formulasi kombinasi kedua ekstrak tersebut.

Dari hasil pengujian aktivitas farmakologi herba sambiloto yang telah dilakukan, diketahui bahwa sambiloto berkhasiat sebagai antibakteria (Sule et al., 2010), antidiabetes mellitus (Zhang \& Tan, 2000b), dan antiinflamasi (Chao, et al., 2010),. Penelitian khasiat 
sambiloto sebagai agen antidiabetes telah banyak dilakukan antara lain oleh Zhang dan Tan (2000a). Sambung nyawa telah lama digunakan dalam pengobatan seperti antihiperglikemik dan antihiperlipidemia (Zhang \& Tan, 2000b), antiinflamasi (Iskander et al., 2002; Tan et al., 2016), antikarsinogen (Agustina, et al., 2006), penurun tekanan darah (Hoe et al., 2007; Kaur et al., 2013; Kim et al., 2006), antiproliferasi pada human mesangial cell (Tan et al., 2016), antioksidan (Puangpronpitag et al., 2010; Rosidah et al., 2009), dan anti ulcer (Mahmood et al., 2010).

Khasiat hipoglikemik kombinasi ekstrak larut etanol herba sambiloto dan daun sambung nyawa pernah diteliti oleh (Sari et al., 2015) pada tahun 2015 dan menunjukkan bahwa pemberian kombinasi ekstrak larut etanol herba sambiloto dan daun sambung nyawa dapat menurunkan kadar glukosa darah preprandial dan postprandial pada tikus terinduksi aloksan dengan daya hipoglikemik yang lebih baik daripada ekstrak tunggalnya. Selain itu, diketahui bahwa pemberian kombinasi ekstrak larut etanol herba sambiloto dan daun sambung nyawa, secara kualitatif dapat memperbaiki morfologi kerusakan pulau Langerhans dan ekspresi insulin pankreas pada tikus terinduksi aloksan.

Studi toksisitas akut ekstrak sambiloto secara tunggal telah dilakukan oleh (Chandrasekaran et al., 2009). Pada penelitian tersebut menunjukkan bahwa pemberian ekstrak sambiloto pada dosis hingga $5000 \mathrm{mg} / \mathrm{kgBB}$ tidak menunjukkan tanda-tanda toksisitas pada hewan uji. Oleh karena itu, ekstrak sambiloto dapat dikategorikan dalam kategori aman. Toksisitas ekstrak sambung nyawa secara tunggal telah diteliti sebelumnya. (Algariri et al., 2014) menyebutkan bahwa hasil dari studi toksisitas akut dan subkronis yang telah dilakukan berdasarkan OECD 425 dan 407 menunjukkan nilai LD $_{50}$ melebihi dosis 2000 $\mathrm{mg} / \mathrm{kg}$. Oleh karena itu, ekstrak sambung nyawa masuk dalam kategori aman secara biokimia dan hematologi.

Adanya potensi yang baik dari kombinasi herba sambiloto dan daun sambung nyawa untuk dikembangkan menjadi alternatif pengobatan dalam penyakit hiperglikemik, mendorong peneliti untuk menguji keamanan kombinasi tanaman tersebut. Oleh karena itu, melalui penelitian ini akan dilakukan pengujian toksisitas akut kombinasi ekstrak larut etanol herba sambiloto dan daun sambung nyawa untuk melihat keamanan setelah dipaparkan terhadap hewan uji dalam 24 jam. Sehingga akan dapat diperoleh informasi sifat ketoksikan akut kombinasi ekstrak larut etanol herba sambiloto dan daun sambung nyawa yang akan menjadi dasar pengembangan kombinasi kedua ekstrak tersebut. 


\section{Metodologi penelitian}

\subsection{Deskripsi bahan}

Bahan pembuatan ekstrak adalah herba sambiloto (Andrographis paniculata (Burm. f) Ness) dari daerah Sidoarum Sleman, daun sambung nyawa (Gynura procumbens (Lour.) Merr) dari daerah Sidoarum Sleman, dan etanol 70\%. Bahan lain yang digunakan selama penelitian yaitu akuades, CMC Na $0.5 \%$, buffer formalin $10 \%, \mathrm{NaCl}$ fisiologis, dan pewarna HematoxillinEosin.

\subsection{Proses pembuatan ekstrak sambiloto dan sambung nyawa}

Herba sambiloto dan daun sambung nyawa yang telah dipanen kemudian dikeringkan di bawah sinar matahari. Simplisia yang telah kering kemudian diserbuk dengan grinder. Serbuk herba Sambiloto (1022,2 gram) dan daun Sambung nyawa (1164,6 gram) diekstraksi dengan metode maserasi secara terpisah menggunakan pelarut etanol 70\% (perbandingan 1:10). Proses maserasi pertama dilakukan pada suhu kamar selama 3 hari dan dilakukan pengadukan secara berkala. Setelah diremaserasi dua kali masing-masing 3 hari, filtrat yang diperoleh dikumpulkan dan kemudian dievaporasi hingga diperoleh ekstrak kental.

\subsection{Pengujian toksisitas akut}

Uji toksisitas akut dilakukan berdasarkan metode OECD 423 (OECD, 2002). Sebelum perlakuan, hewan uji tikus betina galur Wistar diaklimatisasi pada kandang uji selama 7 hari dan dipantau berat badannya. Sebanyak 15 hewan uji kemudian dibagi menjadi 5 kelompok perlakuan, yang terdiri dari 1 kelompok kontrol dan 4 kelompok uji (kelompok perlakuan pelarut, kelompok perlakuan ekstrak etanol herba sambiloto tunggal, kelompok perlakuan ekstrak etanol daun sambung nyawa tunggal, kelompok perlakuan kombinasi ekstrak etanol herba sambiloto dan daun sambung nyawa dengan masing-masing jumlah hewan uji per kelompok adalah tiga ekor.

Untuk sampel uji kombinasi ekstrak larut etanol herba sambiloto dan daun sambung nyawa, masing-masing ekstrak ditimbang sesuai proporsi dengan perbandingan komposisi $100 \mathrm{mg}$ ekstrak larut etanol herba sambiloto dan $112 \mathrm{mg}$ ekstrak larut etanol daun sambung nyawa. komposisi ekstrak yang dipilih berdasarkan hasil penelitian Sari et al (2015) yang menyatakan bahwa perbandingan optimal kedua ekstrak sebagai agen hipoglikemik adalah 
100 mg ekstrak sambiloto dan 112 mg ekstrak sambung nyawa. Ekstrak uji kombinasi ini kemudian dihomogenkan dan disuspensikan dengan CMC Na menjadi sediian uji kelompok ekstrak kombinasi sambiloto dan sambung nyawa.

Pada tahap pertama, dosis yang diberikan terhadap hewan uji (15 ekor) merupakan dosis tunggal yang diberikan secara peroral dengan dosis awal adalah $300 \mathrm{mg} / \mathrm{kgBB}$. Pengamatan yang dilakukan meliputi pengamatan perilaku hewan uji terhadap gejala toksik selama 4 jam setelah pemberian sediaan uji, kemudian dilanjutkan selama 24 jam dan dihitung jumlah hewan uji yang mati di setiap kelompoknya, serta dilakukan penimbangan bobot hewan uji pada hari ke-0, ke-7, dan ke-14 setelah perlakuan. Pada tahap kedua, dosis paparan akut dinaikkan menjadi $2000 \mathrm{mg} / \mathrm{kgBB}$ dengan jumlah hewan uji yang sama karena pada dosis sebelumnya tidak ditemukan adanya hewan uji yang mati.

Setelah selesai masa uji, seluruh hewan uji yang masih hidup dikorbankan dan dibedah untuk diambil organ vitalnya. Organ vital yang terdiri dari hepar, usus, ginjal, dan lambung ditimbang bobotnya sedangkan untuk organ hepar dimasukkan ke dalam pot plastik berisi larutan buffer formalin 10\%, untuk selanjutnya dilakukan pembuatan preparat untuk melihat gambaran histopatologis tikus pada tiap kelompok perlakuan. Pembuatan preparat dan pewarnaan hematoxylin eosin (HE) dilakukan di Laboratorium Balai Besar Veteriner Wates. Pewarna HE merupakan senyawa pewarna yang umum digunakan untuk sel dan jaringan. Hematoksilin akan mengecat inti sel menjadi berwarna biru sedangkan eosin akan mengecat sitoplasma dan matriks ekstraseluler menjadi berwarna merah. Pengamatan perubahan histologis hati tikus dilakukan dengan bantuan mikroskop cahaya pada pembesaran 10x10 dan 10x40 untuk mengidentifikasi sel-sel hepar yang mengalami degenerasi dan nekrosis kemudian dibandingkan dengan kondisi organ hepar hewan uji kelompok kontrol yang hanya diberi pelarut.

\section{Hasil dan pembahasan}

Penelitian ini sebelumnya telah mendapatkan ijin ethical clearance dari tim Etik Penelitian Fakultas Kesehatan Universitas Jenderal Achmad Yani Yogyakarta dengan Nomor Skep/0170/KEPK/VII/2019. Pada penelitian ini, diperoleh rendemen ekstrak kental sambiloto sebesar 9,7\% dan rendemen ekstrak kental sambung nyawa sebesar 8,1\%. Hasil rendemen ekstrak sambiloto yang diperoleh memenuhi nilai yang dipersyaratkan Farmakope 
Herbal Indonesia (FHI) tahun 2010 yaitu tidak kurang dari 9,6\%. Hasil rendemen ekstrak kental sambung nyawa juga memenuhi persyaratan FHI yaitu tidak kurang dari 7,2\%.

Hasil uji organoleptik ekstrak sambiloto yang diperoleh adalah berwarna hijau kecoklatan, bau khas pahit, konsistensi kental dan lengket, dan rasa sangat pahit. Sedangkan hasil uji organoleptik ekstrak daun sambung nyawa adalah berwarna hijau pekat, bau khas, konsistensi kental, dan rasa pahit. Uji organoleptik bertujuan untuk memberikan pengenalan awal ekstrak secara objektif berupa bentuk, warna, bau, dan rasa. Data ini juga dapat digunakan sebagai dasar untuk menguji ekstrak secara fisis selama penyimpanan. Uji organoleptik yang dilakukan meliputi pengamatan terhadap warna, bau, rasa dan konsistensi dari masing-masing ekstrak. Hasil uji organoleptik ekstrak berupa warna yang menunjukkan hasil ekstrak kental sambiloto bewarna hijau kecokelatan adalah akibat dari terjadinya polimerisasi senyawa fenolik dalam ekstrak sambiloto. Rasa pahit pada ekstrak sambung nyawa dapat disebabkan oleh kandungan senyawa turunan seskuiterpen lakton yang terdapat pada tanaman suku Asteraceae sedangkan pada ekstrak sambiloto rasa pahit akibat adanya kandungan metabolit turunan diterpen lakton seperti andrografolid.

Dosis yang diberikan pada hewan uji dimulai dari dosis $300 \mathrm{mg} / \mathrm{kg}$ BB sesuai petunjuk OECD 423 untuk senyawa bahan alam yang belum ada informasi dosis toksiknya dengan perhitungan volume pemberian maksimal $3 \mathrm{~mL}$ untuk tikus berbobot 200 gram. Dosis kemudian dinaikkan menjadi $2000 \mathrm{mg} / \mathrm{kg}$ BB sesuai dengan panduan OECD 423 dengan aturan volume pemberian yang sama. Pada pengujian tahap 1 dan tahap 2, pengamatan dilakukan selama 24 jam setelah pemberian sediaan uji dengan masa pengamatan intensif adalah 4 jam setelah paparan akut. Apabila ada hewan uji yang mati sebelum 24 jam maka hewan uji tersebut segera dibedah, diambil organ vitalnya seperti hati, ginjal, usus halus, jantung, dan lambung untuk diamati secara makroskopis. Pada kasus ini tikus yang dipejani sediaan uji tidak ada yang mengalami kematian pada dosis $300 \mathrm{mg} / \mathrm{kgBB}$ dan $2000 \mathrm{mg} / \mathrm{kgBB}$ pada 24 jam pertama baik pemberian pertama maupun pengulangan pada hewan yang berbeda hingga hari ke 14 penelitian. Sehingga pada hari ke 14 hewan uji dikorbankan untuk melihat efek tertunda yang mungkin muncul. Pengamatan secara mikroskopis dilakukan pada 4 organ vitalnya yaitu hati, ginjal, usus, dan lambung.

Tidak terdapat perubahan yang signifikan pada pengamatan kualitatif berupa gejala klinis pada kulit dan bulu, membran mukosa, sistem pernapasan, sistem sirkulasi, somatomotor, mata, sistem otonom, perilaku dan koma pada seluruh kelompok perlakuan 
setelah pengamatan intensif selama 4 jam dan 24 jam setelah paparan senyawa uji. Seluruh hewan uji masih bersifat normal dan tidak ada keanehan dalam perilaku. Efek menegangnya bulu hewan uji hanya terlihat sementara segera setelah pemaparan yang mungkin diakibatkan stress-nya hewan uji karena menerima dosis paparan yang tinggi.

Jumlah kematian hewan uji pada masing-masing kelompok kontrol maupun kelompok dosis setelah pemberian ekstrak larut etanol herba sambiloto, daun sambung nyawa, dan kombinasi keduanya dapat dilihat pada Tabel 2. Pada tabel tersebut dapat dilihat bahwa pada tahap pertama, tidak ditemukan adanya hewan uji yang mati sehingga dilanjutkan dengan tahap ke-2 dan setelah akhir masa uji tidak ditemukan hewan uji yang mati.

Tabel 1. Perbandingan jumlah hewan uji antar kelompok perlakuan selama masa uji

\begin{tabular}{|c|c|c|c|c|c|}
\hline \multirow[t]{2}{*}{ Kelompok Perlakuan } & \multirow[t]{2}{*}{$\begin{array}{l}\text { Jumlah Tikus } \\
\text { Awal (ekor) }\end{array}$} & \multicolumn{2}{|c|}{$\begin{array}{c}\text { Jumlah Tikus } \\
\text { Akhir Tahap I } \\
\text { (ekor) }\end{array}$} & \multicolumn{2}{|c|}{$\begin{array}{c}\text { Jumlah Tikus } \\
\text { Akhir Tahap II } \\
\text { (ekor) }\end{array}$} \\
\hline & & Mati & Hidup & Mati & Hidup \\
\hline Kontrol Normal & 3 & 0 & 3 & 0 & 3 \\
\hline Kontrol Pelarut & 3 & 0 & 3 & 0 & 3 \\
\hline $\begin{array}{l}\text { Ekstrak Sambiloto Tunggal } \\
\qquad(100 \mathrm{mg} / \mathrm{kgBB})\end{array}$ & 3 & 0 & 3 & 0 & 3 \\
\hline Ekstrak Sambung Nyawa & 3 & 0 & 3 & 0 & 3 \\
\hline \multicolumn{6}{|l|}{ Tunggal (112 mg/kgBB) } \\
\hline Ekstrak Kombinasi & 3 & 0 & 3 & 0 & 3 \\
\hline \multicolumn{6}{|l|}{ Sambiloto (100 mg/kgBB) - } \\
\hline \multicolumn{6}{|l|}{$\mathrm{mg} / \mathrm{kgBB})$} \\
\hline Jumlah & 15 & 0 & 15 & 0 & 15 \\
\hline
\end{tabular}

Pada penelitian ketoksikan akut data perubahan berat badan hewan uji merupakan salah satu parameter yang digunakan untuk mengevaluasi kondisi kesehatan secara umum dari hewan uji. Pengamatan ini dapat digunakan untuk mempelajari kemungkinan mekanisme efek toksik akibat pemberian sediaan uji. Penimbangan berat badan hewan uji dilakukan pada hari ke-0, yaitu sebelum pemejanan sediaan uji, 
kemudian penimbangan dilakukan lagi sebelum hewan uji dikorbankan. Hewan uji dipelihara sampai 14 hari dan dilakukan penimbangan berat badan pada hari ke 0,7 , dan 14 untuk menghindari terjadinya stres. Salah satu tanda terjadinya ketoksikan adalah adanya penurunan berat badan hewan uji akibat pemaparan sampel uji. Adapun perubahan berat badan hewan uji dapat dilihat pada Gambar 1 dan terlihat jika pemberian sampel uji tidak memepengaruhi berat badan hewan uji selama perlakuan.

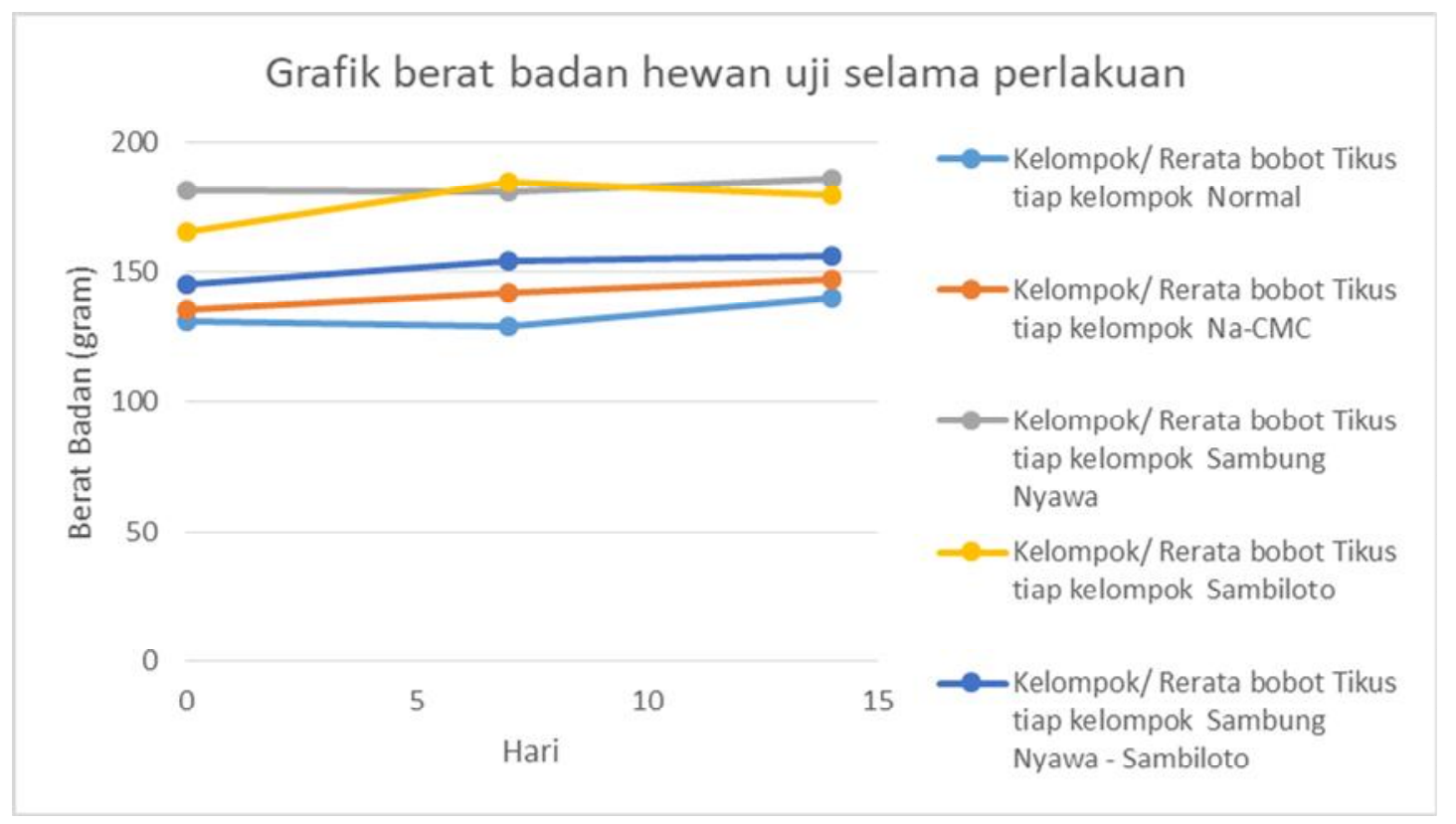

Gambar 1. Grafik berat badan hewan uji selama perlakuan dari hari ke-0, 7, dan 14

Pemeriksaan makroskopis dikenal juga dengan gross patologi. Pemeriksaan gross patologi menggunakan kaca tidak memperlihatkan perbedaan secara kasat mata antara organ vital hewan uji kelompok kontrol dengan perlakuan. Pengamatan makroskopis yang dilakukan terhadap organ vital hewan uji dengan cara mengamati organ hewan uji dibawah lup/kaca pembesar dilengkapi dengan penerangan yang cukup. Hasil pengamatan pada kelompok kontrol Na CMC 0,5\% tidak menunjukkan adanya kerusakan secara kasat mata. Hal yang sama juga terjadi pada kelompok perlakuan dosis $300 \mathrm{mg} / \mathrm{kg}$ BB dan dosis $2000 \mathrm{mg} / \mathrm{kg}$ BB juga tidak menunjukkan adanya kerusakan pada organ hewan uji. Pengamatan makroskopis pada semua kelompok perlakuan selama 14 hari untuk melihat efek yang tertunda tidak menunjukkan adanya kerusakan. Dari hasil pengamatan makroskopis ini masih belum dapat disimpulkan pengaruh sediaan uji terhadap hewan uji karena perlu dilihat hasil pemeriksaan histopatologinya. 
Sedangkan data bobot hewan uji setelah dikorbankan dapat dilihat pada Gambar 2 di bawah ini.

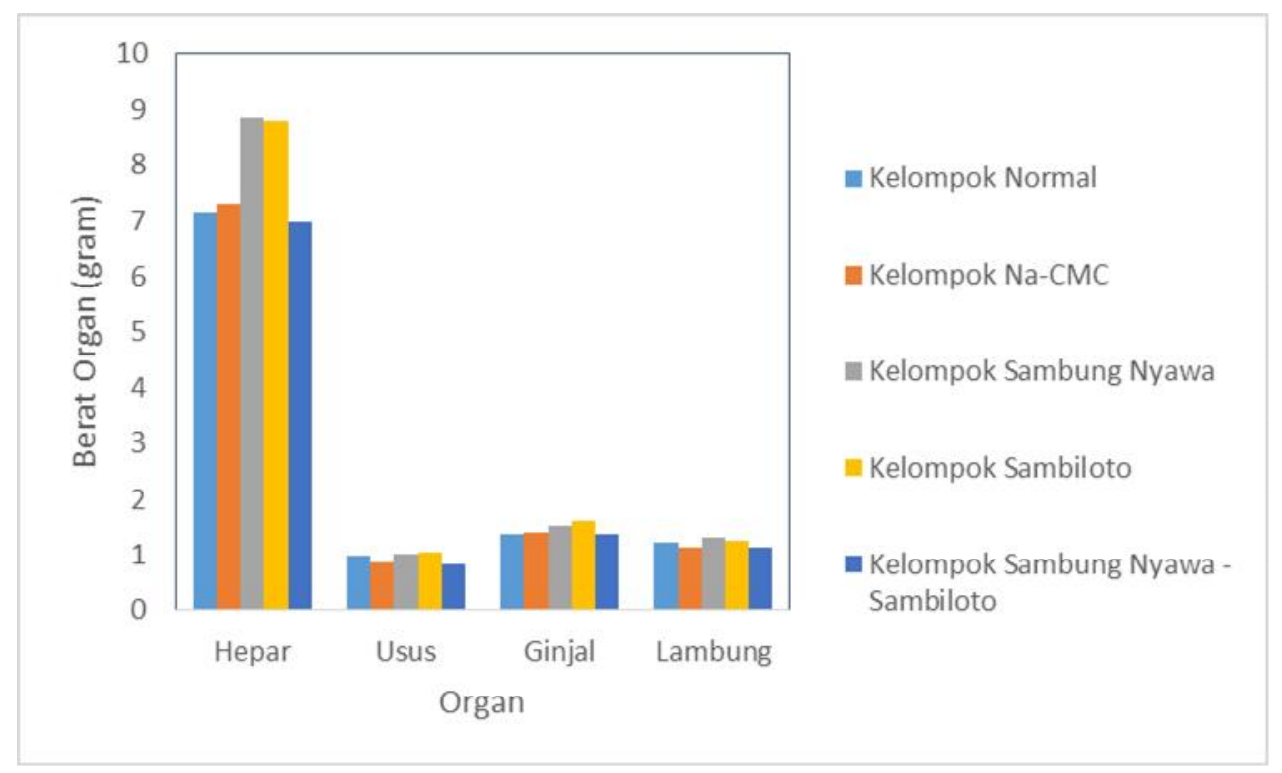

Gambar 2. Grafik bobot organ vital hewan uji yang terdiri dari hepar, usus, ginjal, dan lambung dari tiap kelompok perlakuan

Organ hepar memiliki berbagai fungsi penting dalam tubuh, beberapa diantaranya adalah menetralisir zat toksik, sintesis serum protein, pengaturan nutrisi dan menskresikan garam empedu (Dray, 2011). Berdasarkan hasil interpretasi preparat hispatologi pada organ hepar hewan uji dapat terlihat tidak adanya kerusakan sel kelompok uji kontrol normal (Gambar 3A) dan kelompok kontrol pelarut (Gambar 3B). Pada sel organ hepar, kemungkinan terjadi nekrosis yang ditandai dengan hancur atau hilangnya nukelus (inti sel). Penyebab terjadinya nekrosis adalah adanya toksin atau keracunan. Pada kelompok perlakuan akut senyawa uji ekstrak larut etanol daun sambung nyawa, diketahui bahwa pada histologi organ hepar terjadi pelebaran vena sentralis pada hepar yang kemungkinan disebabkan oleh tingginya kandungan flavonoid pada ekstrak sambung nyawa sebagai antioksidan (Gambar 3C). Tidak ada kerusakan berarti pada organ hepar kelompok perlakuan akut ekstrak larut etanol daun sambung nyawa. Pengamatan preparat organ hepar tikus yang mendapat perlakuan akut senyawa uji ekstrak larut etanol herba sambiloto tunggal dosis $2.000 \mathrm{mg} / \mathrm{kg}$ BB menunjukkan adanya pengecilan ukuran vena sentralis, terjadinya perlemakan hati, dan sinusoid yang ditandai dengan adanya bentuk inti sel yang gepeng dan gelap dengan sedikit 
sitoplasma (Gambar 3D). Pada pengamatan histopatologi organ hepar hewan uji kelompok perlakuan akut kombinasi ekstrak larut etanol herba sambiloto dan daun sambung nyawa dosis $2000 \mathrm{mg} / \mathrm{kgBB}$ terlihat adanya vena sentralis yang berukuran normal dan adanya perlemakan sel hepar (Gambar 3E). Meskipun demikian tidak dijumpai adanya tikus yang mati selama pemberian perlakuan dan secara umum tidak ditemukan adanya kerusakan mayor pada organ hepar hewan uji.

Adanya senyawa flavonoid dan fenolik pada kedua ekstrak tersebut dapat bertindak sebagai antioksidan yang dapat mengurangi efek berbahaya dari senyawa toksin. Mekanisme efek potensiasi ini juga terjadi pada efek kombinasi kedua ekstrak tersebut sebagai agen hipoglikemik. (Sari et al., 2015) menyatakan bahwa tingginya senyawa flavonoid dan fenolik pada ekstrak sambung nyawa dapat membantu efek dari ekstrak sambiloto dalam memperbaiki sel $\beta$ pulau Langerhans yang rusak akibat paparan aloksan sehingga terjadi pengurangan dosis dari ekstrak larut etanol herba sambiloto untuk menimbulkan efek hipoglikemik yang optimal.

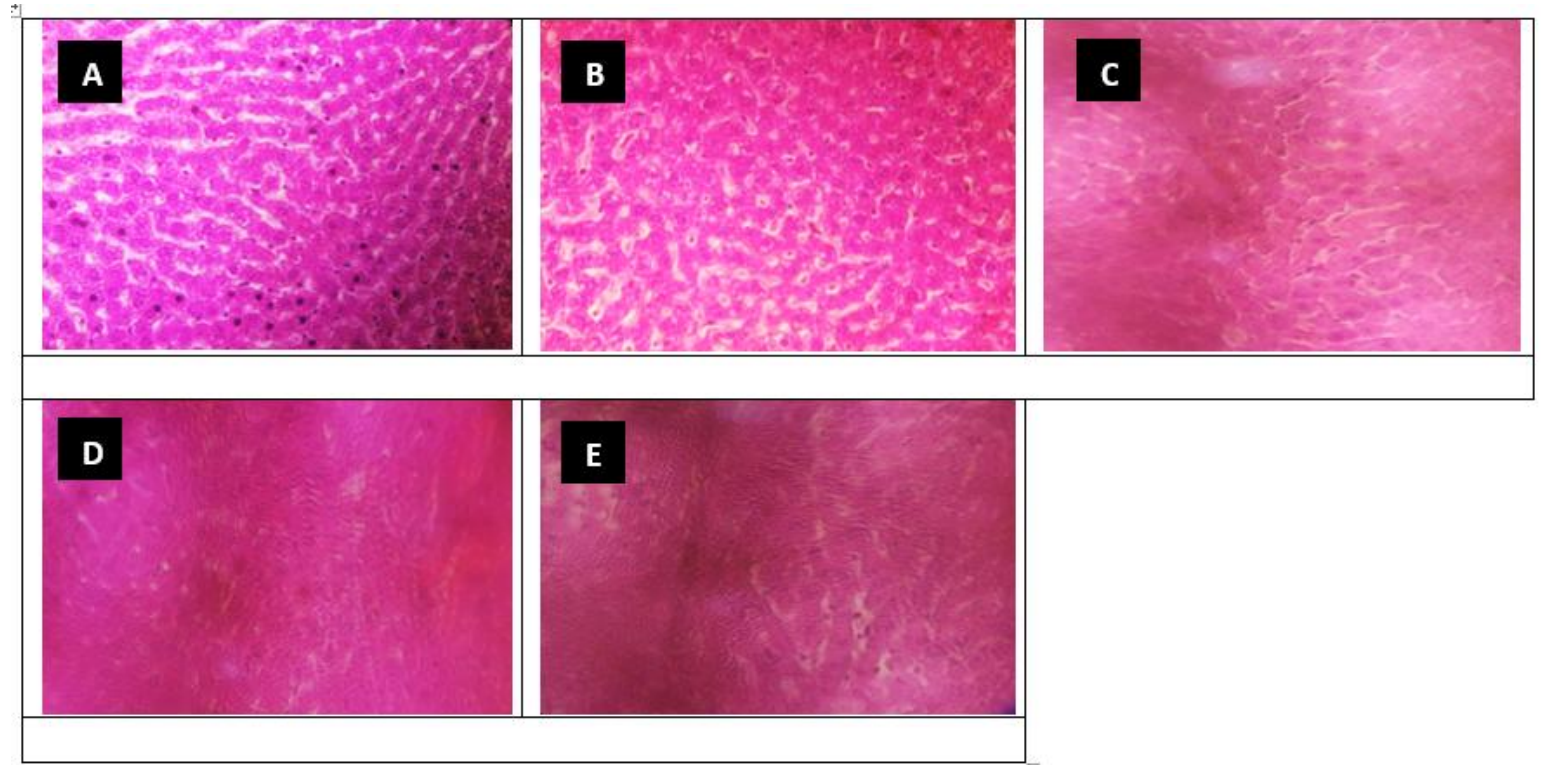

Gambar 3. Gambaran histopatologi hepar tikus dengan pewarnaan HE. (A) tikus normal; (B) kontrol pelarut; (C) ekstrak tunggal sambung nyawa (112 mg/kgBB); (D) ekstrak tunggal sambiloto (100 mg/kgBB); (E) ekstrak kombinasi sambiloto (100 mg/kgBB) dan sambung nyawa (112 mg/kgBB) (perbesaran 400x) 
Berdasarkan hasil kajian toksikologi akut dengan metode OECD 423 dan dilanjutkan dengan pemeriksaan histopatologi organ hepar hewan uji setelah paparan dosis 2000 $\mathrm{mg} / \mathrm{kgBB}$, maka dapat diketahui bahwa sampel uji kombinasi ekstrak larut etanol herba sambiloto dan daun sambung nyawa setelah pengujian toksisitas akut dengan metode OECD 423 tidak menunjukkan tanda toksisitas pada hewan uji. Hal ini didasarkan pada tidak adanya tanda-tanda toksisitas yang muncul setelah paparan akut sampel uji, tidak adanya hewan uji yang mati setelah paparan sampel uji, dan tidak adanya perubahan yang signifikan terhadap berat badan hewan uji yang diamati hingga 14 hari setelah paparan sampel uji.

Hasil penelitian menunjukkan bahwa pemaparan secara akut kombinasi ekstrak larut etanol herba sambiloto dan daun sambung nyawa pada hewan uji hingga dosis $2000 \mathrm{mg} / \mathrm{kgBB}$ tidak menunjukkan adanya kematian maupun gejala toksik pada hewan uji, sehingga kombinasi ekstrak larut etanol herba sambiloto dan daun sambung nyawa masuk dalam kategori unclassified (>2000mg/kgBB) menurut Globally Harmonized Classification System (GHS) (OECD, 2002). Sampel uji kombinasi ekstrak larut etanol herba sambiloto dan daun sambung nyawa berdasarkan pengamatan gross anatomi pada organ vital hewan uji tidak ditemukan adanya kerusakan dibandingkan dengan hewan uji normal. Hewan uji yang diberi paparan sampel uji kombinasi ekstrak larut etanol herba sambiloto dan daun sambung nyawa tidak menunjukkan adanya kerusakan histopatologi mayor apabila dibandingkan dengan gambaran pada hepar tikus normal.

\section{Kesimpulan}

Kombinasi ekstrak larut etanol herba sambiloto dan daun sambung nyawa tidak menunjukkan tanda toksisitas pada hewan uji setelah paparan akut sesuai metode OECD 423 dan masuk dalam kategori unclassified (>2000mg/kgBB) menurut Globally Harmonized Classification System (GHS). Oleh karena itu kombinasi kedua ekstrak ini berpotensi untuk dikembangkan menuju proses formulasi optimal sebagai produk hipoglikemik dan dapat dilanjutkan pada pengujian toksisitas sub kronis.

\section{Ucapan terimakasih}

Terima kasih kami ucapkan kepada Kemenristek DIKTI yang telah mendanai penelitian ini dan Fakultas Kesehatan Universitas Jenderal Achmad Yani Yogyakarta yang telah turut mendukung terlaksananya penelitian ini. 


\section{Daftar pustaka}

Agustina, D., Wasito, W., Haryana, S. M., \& Supartinah, A. (2006). Anticarcinogenesis effect of Gynura procumbens (Lour) Merr on tongue carcinogenesis in 4NQO-induced rat. Dental Journal (Majalah Kedokteran Gigi), 39 (3), 126-132.

Algariri, K., Atangwho, I. J., Meng, K. Y., Asmawi, M. Z., Sadikun, A., \& Murugaiyah, V. (2014). Antihyperglycaemic and toxicological evaluations of extract and fractions of Gynura procumbens leaves. Trop Life Sci Res. 25(1), 75-93.

Chandrasekaran, C. V., Thiyagarajan, P., Sundarajan, K., Goudar, K. S., Deepak, M., Murali, B., ... Agarwal, A. (2009). Evaluation of the genotoxic potential and acute oral toxicity of standardized extract of Andrographis paniculata (KalmCold ${ }^{\mathrm{TM}}$ ). Food Chem Toxicol, 47(8), 1892-902.

Chao, W. W., Kuo, Y. H., \& Lin, B. I. F. (2010). Anti-inflammatory activity of new compounds from Andrographis paniculata by nf-kb transactivation inhibition. J Agric Food Chem, 58(4), 2505-12.

Dray, N. (2011). Harrison's Hematology and Oncology. The Yale Journal of Biology and Medicine.

Hoe, S. Z., Kamaruddin, M. Y., \& Lam, S. K. (2007). Inhibition of angiotensin-converting enzyme activity by a partially purified fraction of Gynura procumbens in spontaneously hypertensive rats. Med Princ Pract, 16(3), 203-8.

Iskander, M. N., Song, Y., Coupar, I. M., \& Jiratchariyakul, W. (2002). Antiinflammatory screening of the medicinal plant Gynura procumbens. Plant Foods for Human Nutrition, 57, 233-244.

Kaur, N., Kumar, R., Yam, M. F., Sadikun, A., Sattar, A. M. Z., \& Asmawi, M. Z. (2013). Antihypertensive effect of Gynura procumbens water extract in spontaneously hypertensive rats. International Journal of Applied Research in Natural Products, 6(3), 2027.

Kim, M. J., Lee, H. J., Wiryowidagdo, S., \& Kim, H. K. (2006). Antihypertensive effects of Gynura procumbens extract in spontaneously hypertensive rats. J Med Food, 9(4), 587-90.

Mahmood, A. A., Mariod, A. A., Al-Bayaty, F., \& Abdel-Wahab, S. I. (2010). Anti-ulcerogenic activity of Gynura procumbens leaf extract against experimentally-induced gastric lesions in rats. Journal of Medicinal Plants Research, 4(8), 685-691.

OECD. (2002). OECD series on testing and assessment number 23 guidance document on aquatic toxicity testing of. In OECD Series on Testing and Assessment.

Puangpronpitag, D., Chaichanadee, S., Naowaratwattana, W., Sittiwet, C., Thammasarn, K., Luerang, A., \& Kaewseejan, N. (2010). Evaluation of nutritional value and antioxidative properties of the medicinal plant Gynura procumbens extract. Asian Journal of Plant Sciences, 9(3), 146-151.

Reyes, B. A. S., Bautista, N. D., Tanquilut, N. C., Anunciado, R. V., Leung, A. B., Sanchez, G. C., ... Maeda, K. I. (2006). Anti-diabetic potentials of Momordica charantia and Andrographis paniculata and their effects on estrous cyclicity of alloxan-induced diabetic rats. $J$ Ethnopharmacol, 105(1-2), 196-200.

Rosidah, Yam, M. F., Sadikun, A., Ahmad, M., Akowuah, G. A., \& Asmawi, M. Z. (2009). Toxicology evaluation of standardized methanol extract of Gynura procumbens. $J$ Ethnopharmacol, 123(2), 244-9.

Sari, K. R. P., Sudarsono, \& Nugroho, A. E. (2015). Effect of herbal combination of Andrographis paniculata (Burm.f) Ness and Gynura procumbens (Lour.) Merr ethanolic extracts in alloxan-induced hyperglycemic rats. International Food Research Journal, 22(4), 1332- 
1337.

Sule, a, Ahmed, Q., \& Samah, O. (2010). Screening for antibacterial activity of Andrographis paniculata used in malaysian folkloric medicine: A possible alternative for the treatment of skin infections. Ethnobotanical Leaflets, 14, 445-56.

Tan, H. L., Chan, K. G., Pusparajah, P., Lee, L. H., \& Goh, B. H. (2016). Gynura procumbens: An overview of the biological activities. Frontiers in Pharmacology, 7, 52.

Zhang, X. F., \& Tan, B. K. H. (2000a). Anti-diabetic property of ethanolic extract of Andrographis paniculata in streptozotocin-diabetic rats. Acta Pharmacologica Sinica, 21(12), 1157-64.

Zhang, X. F., \& Tan, B. K. H. (2000b). Antihyperglycaemic and anti-oxidant properties of Andrographis paniculata in normal and diabetic rats. Clin Exp Pharmacol Physiol, 27(5-6), 358-63. 